\title{
High-resolution bathymetry using Alvin scanning sonar at the Southern East Pacific Rise and its implication to the formation of collapsed lava lakes
}

\author{
Akiko Tanaka ${ }^{1}$, Severine Rosat ${ }^{1,2}$, Kiyoyuki Kisimoto ${ }^{1}$, and Tetsuro Urabe ${ }^{1,3}$ \\ ${ }^{1}$ Geological Survey of Japan, AIST, Tsukuba Central 7, 1-1-1 Higashi, Tsukuba, Ibaraki 305-8567, Japan \\ ${ }^{2}$ Ecole et Observatoire des Sciences de la Terre, Strasbourg, France \\ ${ }^{3}$ Department of Earth \& Planetary Science, University of Tokyo, Japan
}

(Received September 8, 2005; Revised December 9, 2006; Accepted December 16, 2006; Online published May 7, 2007)

\begin{abstract}
A high-resolution bathymetric map of a collapsed lava lake on the ridge crest of the superfast-spreading Southern East Pacific Rise was constructed. The data were acquired during the MOAI'98 Cruise using a pencilbeam scanning sonar that was installed on the submersible Alvin. The map covers an area of $200 \times 350 \mathrm{~m}$ at the Oasis hydrothermal site $\left(17^{\circ} 25.4^{\prime} \mathrm{S}, 113^{\circ} 12.3^{\prime} \mathrm{W}\right)$ where low-temperature fluids are venting from a collapsed lava lake. The collapsed lava lake is $250 \mathrm{~m}$ long, with a mean width of $10 \mathrm{~m}$ in parallel to the spreading axis on the western flank of the ridge crest. The estimated volume of lava that has drained out is about $7000 \mathrm{~m}^{3}$ erupted from a single event. This small amount of melt and frequent contacts between "young" and "younger" flows indicate that volcanism at the superfast-spreading ridge system is characterized by frequent eruptions of very small volumes of magma.
\end{abstract}

Key words: Collapsed lava lake, scanning sonar, East Pacific Rise, hydrothermal activity, submersible Alvin, mid-ocean ridge.

\section{Introduction}

The superfast-spreading East Pacific Rise (EPR), situated between $13^{\circ} \mathrm{S}$ and $19^{\circ} \mathrm{S}$ (Fig. 1(a)), has the highest magmatic, hydrothermal (Urabe et al., 1995; Baker and Urabe, 1996) and biological (Maruyama et al., 1998) fluxes of the mid-oceanic ridges. Many studies have been carried out in this area. A segment around $17.5^{\circ} \mathrm{S}$ on the EPR is underlain by an extremely shallow axial magma chamber (Mutter et $a l ., 1995)$ and has a peak cross-sectional area that is a proxy for high magma supply (Scheirer and Macdonald, 1993). A large hydrothermal plume rich in volatile components, such as methane and sulfur, was observed over the area during the $R / V$ Melville cruise in 1993 (Feely et al., 1994; Ishibashi et al., 1997). This discovery led to subsequent submersible dives at the RM24 site $\left(17^{\circ} 26^{\prime} \mathrm{S}, 113^{\circ} 12^{\prime} \mathrm{W}\right)$ for groundtruthing and long-term monitoring, including those with Shinkai 6500/Yokosuka (Urabe and Lupton, 1995; Embley et al., 1998) and Alvin/Atlantis (Urabe et al., 1999; Sinton et al., 2002). The results of these explorations indicated that the last magmatic event occurred within several years prior to 1994 at the RM24 site where the spreading rate is as high as $140 \mathrm{~mm} /$ year (Embley et al., 1998). Black smoker chimneys were found during the Shinkai 6500 dives in 1997 on fresh lobate lava mounds. Low-temperature diffuse vents ("Oasis site") within an area of older sheet lava were also identified (Fig. 1(b)).

The distribution, volume and other morphological details of volcanic products at mid-oceanic ridges provide im-

Copyright (c) The Society of Geomagnetism and Earth, Planetary and Space Sciences (SGEPSS); The Seismological Society of Japan; The Volcanological Society of Japan; The Geodetic Society of Japan; The Japanese Society for Planetary Sciences; TERRAPUB. portant clues to the frequency and size of eruptive events. For example, detailed bathymetric investigations on midoceanic ridges have suggested a relationship between the volume of magmatic events and the spreading rate (e.g. Perfit and Chadwick, 1998). This relationship predicts that the volume of most eruptions may be small at superfastspreading ridges. In contrast, Embley et al. (1998) found a zero-age lava flow unit, $28 \mathrm{~km}$ in length and varying from $400 \mathrm{~m}$ to $2 \mathrm{~km}$ in width centered around $17^{\circ} 26^{\prime} \mathrm{S}$, about $5 \mathrm{~km}$ south of the Oasis site. This flow unit may be a composite of several recent flows, but distinctions among flows are extremely difficult due partly to the limited number of observations of the area. It is therefore useful to measure the volume of single eruptions at other zero-age lava flows. However, it is hard to do so with multibeam sonar systems installed on ships due to the limitation in resolution. The resolution of ship-mounted bathymetric mapping at mid-oceanic ridge depths of $2000-3000 \mathrm{~m}$ is typically 30-100 m, which is one to two orders of magnitude larger than that of visual observations of the seafloor from submersibles. This discrepancy between bathymetric maps and observation made from a submersible makes the correlation of some geologic and volcanic features difficult. Fine-scale mapping over areas several hundreds of meters on a side is therefore required to fill the gap. Kurras et al. (1998) constructed high-resolution bathymetric maps of two biologically and geologically active areas within the axial summit collapse trough on the EPR at $9^{\circ} 49^{\prime} \mathrm{N}-9^{\circ} 51^{\prime} \mathrm{N}$ using scanning sonar data during 23 Alvin dives over a 5-year period. They mapped $2 \times 10^{4} \mathrm{~m}^{2}$ and $1.1 \times 10^{3} \mathrm{~m}^{2}$ areas at resolutions of $3 \mathrm{~m}$ along the vertical and $5 \mathrm{~m}$ along the horizontal axes. Chadwick et al. (2001) constructed bathy- 


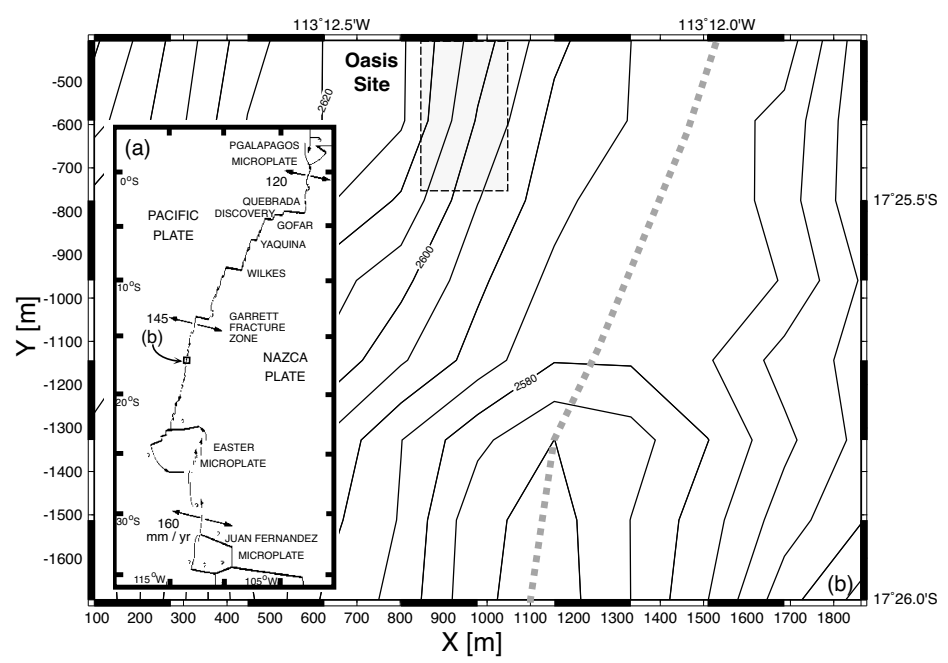

Fig. 1. (a) Geometry of Pacific-Nazca plate boundary (modified after Naar and Hey, 1989). Thick and thin lines are transform faults and ridges, respectively. Solid arrows indicate rifts that appear to be currently propagating. Bold lines having arrows in opposite directions with numbers are full spreading rates in mm/year. (b) Bathymetric contour map of the study area. Gray area is the study area at the Oasis site of RM24, southern East Pacific Rise, at $17^{\circ} 25.4^{\prime} \mathrm{S}$. Thick dotted line indicates the ridge axis.

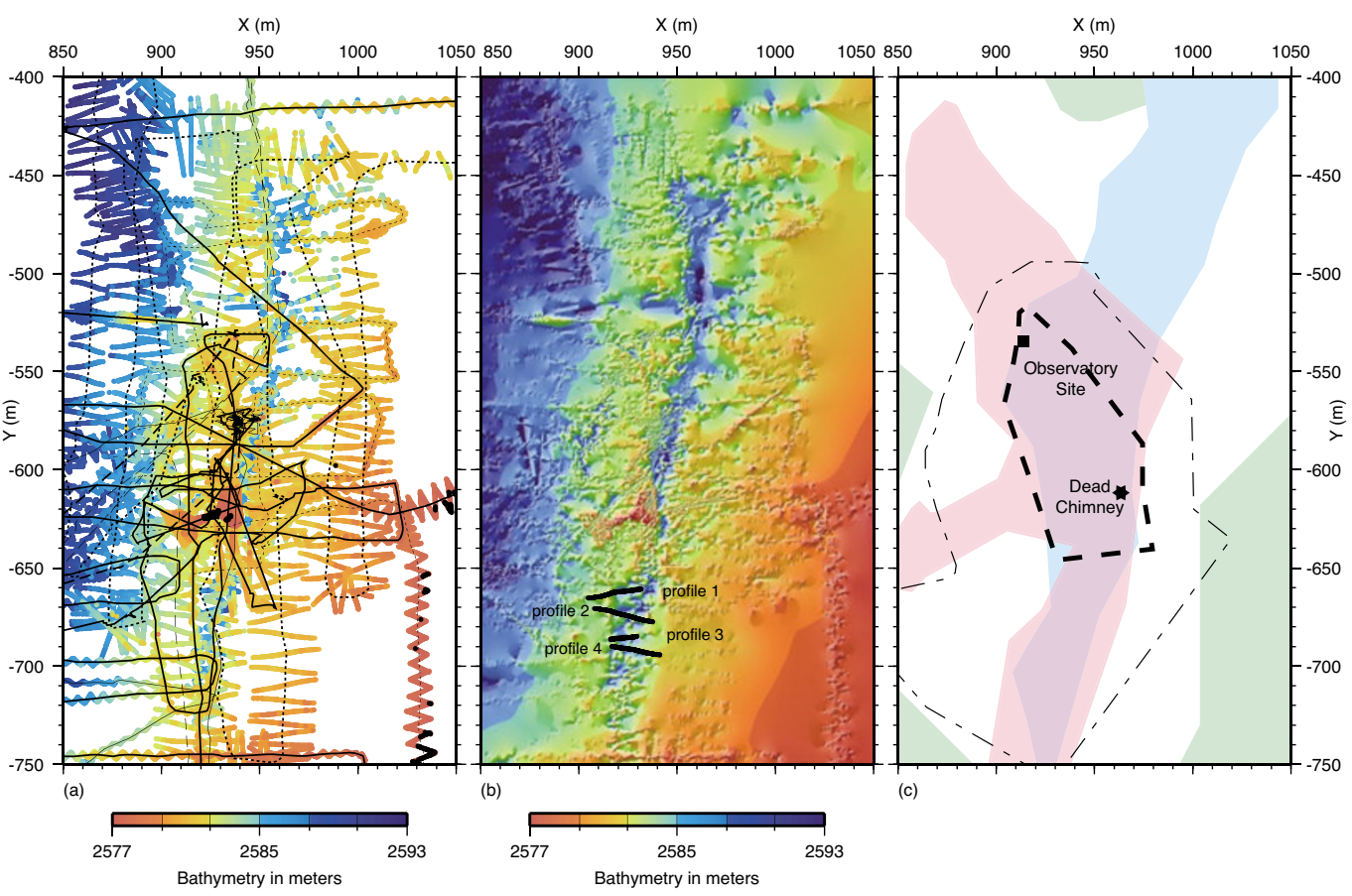

Fig. 2. Maps of the study area at the Oasis site. (a) MESOTECH sonar soundings from six Alvin dives during the MOAI'98 cruise with dive tracklines. Deeper data are overlaid with shallower data. Thick solid, dashed and dotted lines for dive nos. 3273, 3274 and 3275, respectively, and thin solid, dashed and dotted lines for dive nos. 3277, 3278 and 3279, respectively. The $Y$ and $X$ axes correspond to the north-south and east-west directions with the origin at $\left(17^{\circ} 25.080^{\prime} \mathrm{S}, 113^{\circ} 12.853^{\prime} \mathrm{W}\right)$. (b) High-resolution bathymetry (20-cm grid) from the soundings shown in (a). Bold lines show the locations of profiles plotted in Fig. 3. (c) Map of lava morphology and hydrothermal activity constructed from observations on Alvin dive nos. 3273 and 3275. Blue area denotes collapsed lava lake, pink indicates the area of sheet and/or lobate lava flows and the green and white areas are pillow lava flows with and without a dusty sediment cover, respectively. Dense colony (thick dashed line) of hydrothermal fauna is surrounded by a white sea anemone colony (dash-dot line). Note that the hydrothermal activity is limited to the central and southern parts of the collapsed lava lake.

metric maps on 2- or 4-m grids at eight locations on the Co-Axial and Cleft segments of the Juan de Fuca Ridge between 1993 and 1999 using scanning sonar data to map areas from $1 \times 10^{5} \mathrm{~m}^{2}$ to $2 \times 10^{6} \mathrm{~m}^{2}$. The results of both these surveys suggest that high-resolution bathymetry can be used to identify future topographic changes caused by new eruptions.

In this paper, we applied similar methods as those used by
Kurras et al. (1998) and Chadwick et al. (2001) to construct a detailed bathymetric map of the Oasis hydrothermal site. This map reveals the shape, extent and depth of a welldefined collapsed lava lake at the Oasis site that is identified through observation from the submersibles. We estimate the volume of erupted lava and discuss its geologic and volcanic morphology. 


\section{Data and Its Processing}

Bathymetric data used in this paper were acquired on six Alvin dives at the Oasis site (Fig. 2(a)), using a MESOTECH sonar (Model 971). The MESOTECH sonar is a "pencil beam" scanning sonar and produces precise short-range depth profiles along the submersible track. A scanning range of $120^{\circ}$ and a step angle of $0.9^{\circ}$ were chosen for each profile. As Alvin moves forward and the sonar head sweeps from side to side perpendicular to its track, the data are collected in a zigzag pattern. Lower submersible altitudes and/or slower submersible speeds provide higher data resolution, but higher altitudes and/or higher speeds provide greater spatial coverage within a given time period. Data were usually collected at an altitude of $4 \mathrm{~m}$ and a forward speed of 0.5 knots during our surveys to map volcanic features from tens to hundreds of meter in size. This means that Alvin advanced about $2 \mathrm{~m}$ during each sweep, which lasted $8 \mathrm{~s}$. Each swath width was about $14 \mathrm{~m}$, which gives a resolution along the scan direction of about $10 \mathrm{~cm}$.

Alvin was navigated by means of a long baseline system using two transponders with fixes every $15 \mathrm{~s}$. Navigation gaps were filled in based on the assumption that Alvin moved in a straight line between fixes at a constant velocity and heading. We plotted Alvin's position and edited the navigation data to remove outliers by using Alvin's calculated speed between fixes. The high-resolution bathymetric data are the sum of Alvin's depth, estimated from its pressure sensor, and Alvin's altitude, based on the angle and range from the MESOTEC sonar. The bathymetry ranges in this area from about 2500 to $2650 \mathrm{~m}$ as determined from multibeam sonar data. We removed bathymetry outliers in the MESOTECH data outside this depth range. We plotted each dive track with bathymetry, and computed depths among crossing points, and then we eliminated erroneous depths based on video observations and comparisons between known sea-bottom features from other dives. Using these methods, we determined that depths from dive no. 3274 were always deeper; we consequently shifted these upwards by about $1 \mathrm{~m}$ to fit the depth values of other dives.

We used the Generic Mapping Tools software (Wessel and Smith, 1995) to develop a grid map from the scanning sonar data. The data are filtered by the L2 norm to avoid aliasing short wavelengths. We gridded the data using a 20$\mathrm{cm}$ grid cell size with continuous curvature splines in tension. While the spacing of the sonar pings across the track is about $10 \mathrm{~cm}$ assuming an altitude of $4 \mathrm{~m}$, the spacing along the track is not nearly as dense, usually a few meters. However, the detailed structures of the bottom of the depressions, including the lava pillars within them, can only be distinguished by this resolution of $20 \mathrm{~cm}$, as shown in Fig. 3. Also, profiles across and along the collapsed lava lake reveal that bathymetry along it is relatively smoother, and much data were acquired when Alvin's track was almost parallel to it. Therefore, we chose a grid size of 20 $\mathrm{cm}$ to display the maximum possible detail. We used a tension factor of 0.35 for steep topography data. Figure 2(b) presents the detailed bathymetric map of the Oasis site. The spatial coverage of Alvin's tracks was limited because the main purpose of the MOAI'98 cruise was to recover instruments on the seafloor. However, observations made using

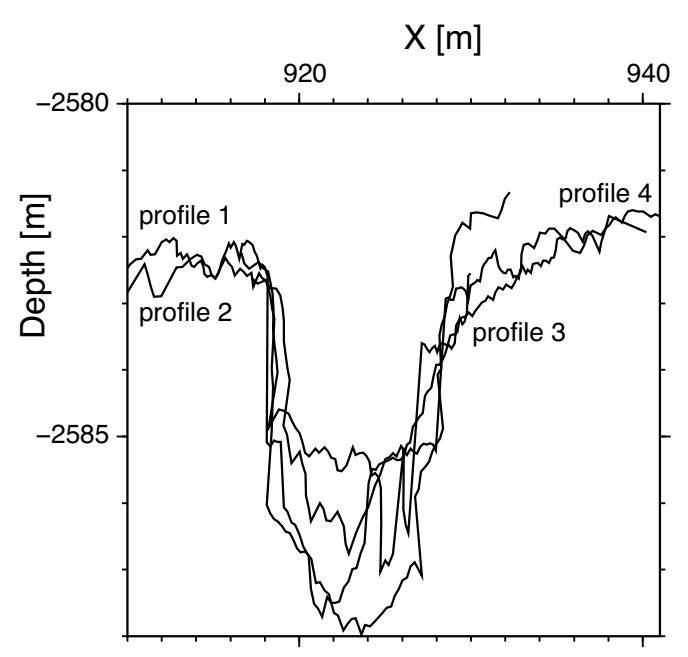

Fig. 3. Raw bathymetric profiles taken almost across the collapsed lava lake.

Alvin reveal that the central depression is $250 \mathrm{~m}$ in length, $10-20 \mathrm{~m}$ in width and approximately $5 \mathrm{~m}$ in depth and that it is elongated almost parallel to the ridge axis with a $15^{\circ} \mathrm{N}$ trend.

\section{Results and Discussion}

This Oasis site is characterized by extremely young lava flows containing numerous collapse pits as well as a general absence of fissures. This area was first discovered during a Nautile dive series in 1993 (Auzende et al., 1996). Additional observations were made in 1994 and 1997 with the Shinkai 6500 (Urabe et al., 1995, Embley et al., 1998) and in 1998 with Alvin (Sinton et al., 2002). Sinton et al. (2002) mapped nine separate lava sequences, including the Aldo-Kihi flow field $\left(17^{\circ} 24^{\prime} \mathrm{S}-17^{\circ} 34^{\prime} \mathrm{S}\right)$, and, using data obtained by submersible dives and a deep-towed, $120-\mathrm{kHz}$ side-scan sonar, they documented that this flow field was built up by multiple eruptive events. The Oasis site forms part of this mapped area. Cormier et al. (2003) targeted the drained lava lake cluster between $17^{\circ} 26^{\prime} \mathrm{S}$ and $17^{\circ} 29^{\prime} \mathrm{S}$ using developments in autonomous underwater vehicles (AUV) and mapped $3 \mathrm{~km}$ of the neovolcanic zone in detail. The Oasis site is a few kilometers north of their target area. A fracture or ditch around the depression in the Oasis site was not observed on the observations and video images obtained by means of the submersible. As shown in Fig. 3, the finest scale bathymetric information from the MESOTECH depth profiles shows steeply dipping walls, lava pillars and irregular floor bathymetry. Based on these observations and information, the central depression is interpreted to be a collapsed lava lake. This collapsed lava lake is elongated almost parallel to the ridge axis and in en echelon, and it may have been formed by a single eruptive event because it is found within young lobate and pillow lavas without a dusty sediment cover, which in turn are surrounded by pillow lavas with a dusty sediment cover (Fig. 2(c)). The Aldo-Kihi flow field comprises many single eruptive events like this one, probably of slightly different ages. Figure 2(c) shows the distribution of lava morphology and hydrothermal activity based on video observations from 


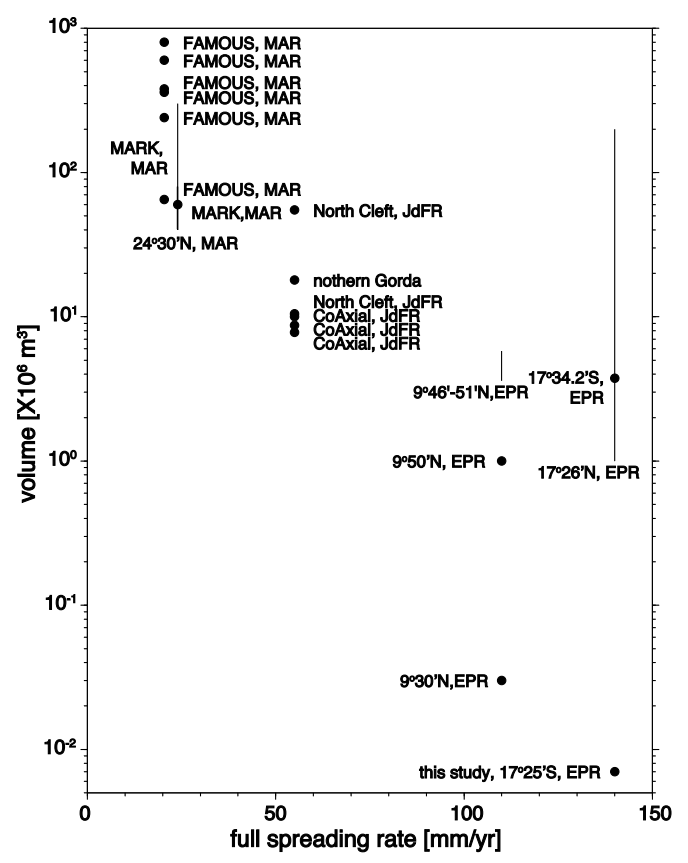

Fig. 4. The estimated volumes from individual eruptive units as a function of full spreading rate. Data from Table 1 in Perfit and Chadwick (1998), Gregg et al. (1996), Embley et al. (1998), Sinton et al. (2002) and this study (Oasis site). Gray lines show the range of estimated volumes.

dive nos. 3273 and 3275 , which surveyed this area thoroughly. The blue area denotes the collapsed lava lake, pink indicates the area of sheet and/or lobate lava flows and the green and white areas are pillow lava flows with and without a dusty sediment cover, respectively. A dense colony (thick dotted line) of hydrothermal fauna, such as Caliptogena sp., Polychaeta, Galatheid crab, Rimicaris shrimp and vent fish, are surrounded by white sea anemone colonies (dash-dot line). There is no hydrothermal activity in the northern part of the collapsed lava lake, and the sheet flows extend obliquely downslope relative to the direction of the collapsed lava lake. This may suggest that the southern and northern parts of the lava lake might have been formed at different times. The sheet flow extends southwestward from point $\mathrm{Y}$ of 600 , where we observed a 5-m-tall dead chimney ("Dead Chimney" in Fig. 2(c)). This distribution of sheet flow is coincident with the bathymetric high in Fig. 2(b). This location might be the center of the most recent eruption which fed a sheet flow that flowed westward toward the western flank of the ridge. The Alvin videos show that pillow lavas with sediment cover are overlain by fresh sheet flow in this area. There are several active vent sites which discharge a milky fluid of up to $6^{\circ} \mathrm{C}$ in temperature in the northern end of the Oasis site, an area called "Observatory site" (Fig. 2(c)), where we placed some long-term monitoring instruments (Urabe et al., 1999). There is neither hydrothermal activity nor biological communities within the depressions to the northeast of "Observatory Site". On the basis of these observations, the most recent collapsed lava lake erupted from the north-south trough, and most of the volume erupted near the "Dead Chimney" site and drained out westward downslope.

The volume of lava erupted in the depression is estimated from the difference between the bathymetry and the precollapsed seafloor before the formation of the depression. The pre-collapsed seafloor is assumed to be the plane specified by the constant contour line that maximizes the ratio of volume to surface area for the bathymetry. This gives a value of about $7000 \mathrm{~m}^{3}$. It should be noted that this value is a minimum estimate, because the following volumes were not added (1) lava that over-flowed the lava lake, and (2) the lava that remained within the collapsed lava lake. However, (1) is negligible because the observed thickness at the fringe of the recent lava flow is always less than $0.5 \mathrm{~m}$ in thickness and is regarded to be within the error of estimation. It is hard to estimate the volume of (2), but the sporadic occurrence of lava pillars within the collapsed lava lake suggests that the drain-out seems to have been fast. We therefore use $7000 \mathrm{~m}^{3}$ as the erupted lava volume that filled the central depression and drained out.

Detailed investigations at a few sites on the mid-ocean ridges since the 1980s have provided insights on the volume of recent magmatic events (Perfit and Chadwick, 1998). Figure 4 shows the relationship between the full spreading rate and erupted volume at mid-ocean ridges; this relationship suggests that the volume of typical eruptions decreases logarithmically with increasing spreading rate. The estimated volumes from individual eruptions are based on repeated multibeam sonar surveys and detailed mapping. Our data are consistent with that obtained in previous studies and is the smallest documented volume of lava erupted from a single event.

\section{Conclusions}

Alvin scanning sonar data were collected during six dives at the Oasis site, a $200 \times 350-\mathrm{m}$ area at the southern EPR $\left(17^{\circ} 25.4^{\prime} \mathrm{S}\right)$. These data were processed and combined to make a high-resolution bathymetric map, gridded at $20 \mathrm{~cm}$. The bathymetric map reveals a topography dominated by a collapsed lava lake, although some artifacts seem to remain around the depression. Near-bottom visual observations of the seafloor from the submersible Alvin and the bathymetry are consistent with each other. We also estimate an erupted volume of $7000 \mathrm{~m}^{3}$, which is consistent with that reported in previous studies, suggesting a logarithmically linear relation between typical erupted volume and spreading rate.

Acknowledgments. We greatly appreciate the contributions of William Chadwick and John Sinton in providing constructive comments and suggestions, which improved the manuscript. We would like to thank the captain, pilots and crews of $R V A t$ lantis/Alvin for their support during data acquisition. The GMT (Generic Mapping Tool) system (Wessel and Smith, 1995) was used to prepare the figures. This research is supported by the Ministry of Education, Science and Technology (MEXT) through Special Coordination Funds "Ridge Flux" and "Archaean Park" projects.

\section{References}

Auzende, J.-M., V. Ballu, R. Batiza, D. Bideau, J.-L. Charlou, M.-H. Cormier, Y. Fouquet, P. Geistodoerfer, Y. Lagabrielle, J. Sinton, and P. Spadea, Recent tectonic, magmatic, and hydrothermal activity on the East Pacific Rise between $17^{\circ} \mathrm{S}$ and $19^{\circ} \mathrm{S}$ : Submersible observations, $J$. Geophys. Res., 101(B8), 17995-18010, 1996.

Baker, E. T. and T. Urabe, Extensive distribution of hydrothermal plumes along the superfast spreading East Pacific Rise, $13^{\circ} 30^{\prime} \mathrm{S}-18^{\circ} 40^{\prime} \mathrm{S}, J$. 
Geophys. Res., 101(B4), 8685-8695, 1996.

Chadwick, W. W., Jr., D. S. Scheirer, R. W. Embley, and H. P. Johnson, High-resolution bathymetric surveys using scanning sonars: Lava flow morphology, hydrothermal vents and geologic structure at recent eruption sites on the Juan de Fuca Ridge, J. Geophys. Res., 106(B8), 1607516100, 2001.

Cormier, M.-H., W. B. F. Ryan, A. K. Shah, W. Jin, A. M. Bradley, and D. R. Yoerger, Waxing and waning volcanism along the East Pacific Rise on a millennium time scale, Geology, 31, 633-636, 2003.

Embley, R. W., J. E. Lupton, G. Massoth, T. Urabe, V. Tunnicliffe, D. A. Butterfield, T. Shibata, O. Okano, M. Kinoshita, and K. Fujioka, Geological, chemical, and biological evidence for recent volcanism at 17.5 S: East Pacific Rise, Earth Planet. Sci. Lett., 163, 131-147, 1998.

Feely, R. A., E. T. Baker, K. Marumo, T. Urabe, J. Ishibashi, J. Gendron, G. T. Lebon, and K. Okamura, Hydrothermal plume particles and dissolved phosphate over the superfast spreading Southern East Pacific Rise, Geochim. Cosmochim. Acta, 60, 2297-2323, 1996.

Gregg, T. K. P., D. J. Fornari, M. R. Perfit, R. M. Haymon, and J. H. Fink, Rapid emplacement of a mid-ocean ridge lava flow on the East Pacific Rise at $9^{\circ} 46^{\prime}-51^{\prime} \mathrm{N}$, Earth Planet. Sci. Lett., 144, E1-E7, 1996.

Ishibashi, J., H. Wakita, K. Okamura, E. Nakayama, R. A. Feely, G. T. Lebon, E. T. Baker, and K. Marumo, Hydrothermal methane and manganese variation in the plume over the superfast spreading southern East Pacific Rise, Geochim. Cosmochim. Acta, 61, 485-500, 1997.

Kurras, G. J., M. H. Edwards, and D. J. Fornari, High-Resolution Bathymetry of the East Pacific Rise Axial Summit Trough $9^{\circ} 49^{\prime}-51^{\prime} \mathrm{N}$ : A Compilation of Alvin Scanning Sonar and Altimetry Data from 19911995, Geophys. Res. Lett., 25, 1209-1212, 1998.

Maruyama, A., T. Urabe, J. Ishibashi, R. A. Feely, and E. T. Baker, Global hydrothermal primary production rate estimated from the southern East Pacific Rise, Cahiers Biol. Mar., 39, 249-252, 1998.

Mutter, J. C., S. M. Carbotte, W. S. Su, L. Q. Xu, P. Buhl, R. S. Detrick, G. M. Kent, J. A. Orcutt, and A. J. Harding, Seismic images of active magma systems beneath the East Pacific Rise between $17^{\circ} 05^{\prime}$ and 17³5'S, Science, 268, 391-395, 1995.

Naar, D. F. and R. N. Hey, Speed limit for oceanic transform faults, Geol- ogy, 17, 420-422, 1989.

Perfit, M. R. and W. W. Chadwick, Jr., Magmatism at mid-ocean ridges: Constraints from volcanological and geochemical investigations, in Faulting and Magmatism at Mid-Ocean Ridges, Geophys. Monogr. Ser., vol. 106, edited by W. R. Buck, P. T. Delaney, J. A. Karson, and Y. Lagabrielle, pp. 59-115, AGU, Washington, D.C., 1998.

Scheirer, D. S. and K. C. Macdonald, The variation in cross-sectional area of the axial ridge along the East Pacific Rise; evidence for the magmatic budget of a fast-spreading center, J. Geophys. Res., 98(B5), 7871-7885, 1993.

Sinton, J., E. Bergmanis, K. Rubin, R. Batiza, T. K. P. Gregg, K. Grönvold, K. C. Macdonald, and S. M. White, Volcanic eruptions on mid-ocean ridges: New evidence from the superfast spreading East Pacific Rise, $17^{\circ}-19^{\circ} \mathrm{S}$, J. Geophys. Res., 107(B6), 2115 , doi:10.1029/2000JB000090, 2002.

Urabe, T., E. T. Baker, J. Ishibashi, R. A. Feely, K. Marumo, G. J. Massoth, A. Maruyama, K. Shitashima, K. Okamura, J. E. Lupton, A. Sonoda, T. Yamazaki, M. Aoki, J. Gendron, R. Green, Y. Kaiho, K. Kisimoto, G. Lebon, T. Matsumoto, K. Nakamura, A. Nishizawa, O. Okano, G. Paradis, K. Roe, T. Shibata, D. Tennant, T. Vance, S. L. Walker, T. Yabuki, and N. Ytow, The effect of magmatic activity on hydrothermal venting along the superfast spreading East Pacific Rise, Science, 269, 1092-1095, 1995.

Urabe, T. and J. E. Lupton, Shinkai 6500 dives under the centers of hydrothermal plumes at superfast-spreading East Pacific Rise between 15.0-18.5 S, EOS Trans. AGU, 76(33), 674, 1995.

Urabe, T., A. Tanaka, and A. Schultz, Long-term temperature and velocity monitoring of low-temperature hydrothermal effluent on Southern East Pacific Rise, EOS Trans. AGU, 80(46), Fall Meet. Suppl., F1098, 1999.

Wessel, P. and W. H. F. Smith, New Version of the Generic Mapping Tools released, EOS Trans. AGU, 76(33), 329, 1995.

A. Tanaka (e-mail: akiko-tanaka@aist.go.jp), S. Rosat, K. Kisimoto, and T. Urabe 